\title{
BREEDING OF THE INDIAN ROOFED TURTLE KACHUGA TECTA IN CAPTIVITY
}

\section{Raju Vyas}

Sayaji Baug Zoo, Vadodara, Gujarat 390018, India.

\begin{abstract}
Breeding biology of the Indian Roofed Turtle (Kachuga tecta) was studied at the Sayaji Baug Zoo, Vadodara, Gujarat during 1991-1999. Courtship was observed from September to January and nesting during October to April with peak in January and February. A total of 34 nests were recorded during the study with an average of 4.85 nests per year. The clutch size was 5.8 eggs, which ranged from 3 to 12 eggs per clutch. Average incubation period was 108 days, which varied from 64 to 195 days. Breeding success was 48.81 per cent, and temperatures played a vital role in the breeding performance of the species.
\end{abstract}

\section{Keywords}

Indian Roofed Turtle, Kachuga tecta, captivity, breeding biology

\section{Introduction}

The Indian Roofed Turtle Kachuga tecta (Gray, 1831) is one of the poorly known Indian turtles. The species is widely distributed in India, Pakistan, Nepal and Bangladesh (Das, 1995). This omnivorous species inhabits slow running rivers and stagnant water bodies such as ponds, puddles, tanks, roadside ditches and nullahs. Entire population of the species lives under abiotic and biotic pressures and the number is reducing drastically in the wild. The habitat of the species has changed or altered in many parts of its distribution range due to anthropogenic interference. In addition, recently it was noticed that a large number of hatchlings of the species are being collected from the wild for national and international pet trades.

Information on the breeding biology of this species is scanty. Mishra (1984) and Moll (1987) provided breeding data of the species in its natural environment, Vijaya (1982) and Vyas and Patel (1993) made an attempt to breed the species in captivity. A compilation of these works is available in Das (1993). The present study was undertaken from August 1991 to August 1999 at Sayaji Baug Zoo, Vadodara, western India, to understand and obtain further information about its breeding biology to support in situ conservation through captive management and restocking in zoos (ex situ).

\section{Materials and Methods}

Eight adult ( 3 males and 5 females) turtles were kept in an enclosure. The enclosure was a rectangular tank of $4 \times 4.5 \mathrm{~m}$ with a half-meter peripheral wall. A sloping pool of $1.5 \times 1.5 \mathrm{~m}$ with half-meter depth was available in the center of the enclosure. The soil of the enclosure was mixed with 50 per cent sand to prevent it from becoming too hard. The top of the enclosure was covered with wire mesh to protect the turtles from predators.

The captive turtles were fed with aquatic vegetation (e.g. Hydrilla verticillata, Lemna gibba, L. perpusilla, Vallisneria sp., V. spiralis, Sagittaria sagittifolia and S. guayanensis) and coriander leaves ad libitum quantity. Data on courtship, nesting and daily activity patterns were noted. The nest was carefully opened on the second day of egg laying, egg size was measured with dial-vernier callipers and weighed using spring balance. The nest size, measurements of inner chamber and depth of buried eggs were recorded.

\section{Results}

Courtship was observed from September to January, which is the cooler season in the state. Males are active during this period and constantly swim behind the females. The male courted the female by swimming alongside or circling the female, rubbing the face and biting her neck. A small tubercle developed at the end of the thick tail of the male, which remained up to March. It is believed to be useful for probing the female's cloaca. I have not done direct observations of the mating process during the study. It is believed that mating takes place at the bottom of the pool. It is difficult to observe due to low visibility in water moreover, any type of movement adds to the disturbance in normal behaviour of the turtles.

Nesting behaviour: Nesting behaviour and related activities were observed during October-April, every year (except 1997-1998). Gravid females nest during 1400-1800 hrs. Females select a suitable site for nesting after making one to four trial nests. Nests were located $6 \mathrm{~cm}$ to $50 \mathrm{~cm}$ away from water. Mean nest dimension of 25 nests was $7 \mathrm{~cm}$ deep and $8 \mathrm{~cm}$ diameter at the inner chamber. 


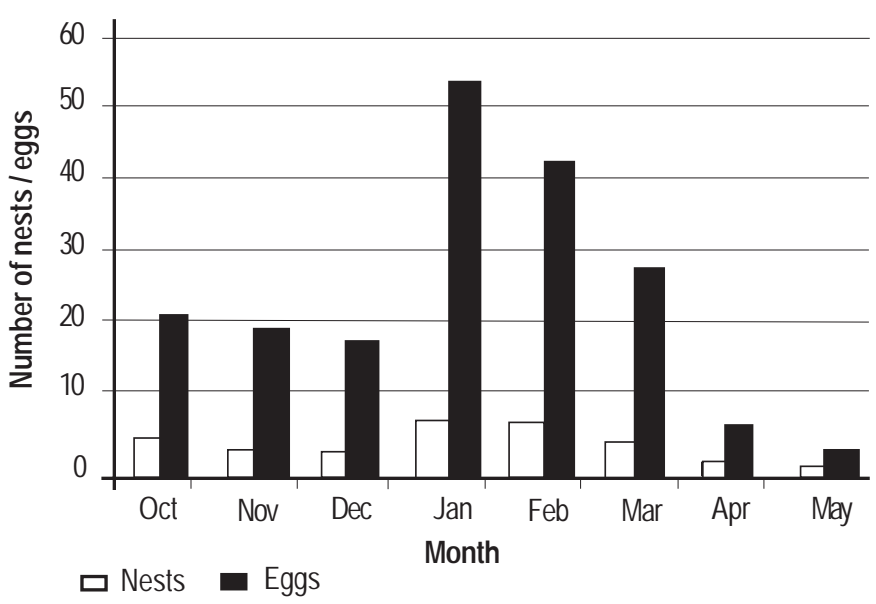

Figure 1. Month-wise number of nests and eggs

The gravid female digs the nest with the help of hind feet the excavation of which takes 45 to 70 minutes. After excavating a nest, eggs were laid one by one in the pit arranged with the help of a hind foot. The female even took care that the egg was not dropped on already laid eggs. Finally, she covered the eggs with soil.

Table 1. Summary of breeding data of Kachuga tecta at Sayaji Baug Zoo, Vadodara, Gujarat (1991-1999)

\begin{tabular}{|c|c|c|c|c|c|c|c|c|}
\hline Year & NC & CS & $\mathrm{NE}$ & NM & IP & NS & HM & $\%$ \\
\hline $1991-92$ & 4 & $\begin{array}{l}5.7 \\
(5-7)\end{array}$ & 23 & $\begin{array}{l}\text { Nov.- } \\
\text { Apr. }\end{array}$ & $\begin{array}{l}65 \\
(64-66)\end{array}$ & 7 & $\begin{array}{l}\text { May- } \\
\text { Jun. }\end{array}$ & 30.43 \\
\hline $1992-93$ & 5 & $\begin{array}{l}7.2 \\
(5-10)\end{array}$ & 36 & $\begin{array}{l}\text { Feb.- } \\
\text { Mar. }\end{array}$ & $\begin{array}{l}81 \\
(71-98)\end{array}$ & 20 & May & 55.55 \\
\hline $1993-94$ & 6 & $\begin{array}{l}5.5 \\
(4-6)\end{array}$ & 33 & $\begin{array}{l}\text { Oct.- } \\
\text { Jan. }\end{array}$ & $\begin{array}{l}123 \\
(90-168)\end{array}$ & 26 & Apr. & 78.78 \\
\hline $1994-95$ & 5 & $\begin{array}{l}4.8 \\
(3-9)\end{array}$ & 24 & $\begin{array}{l}\text { Nov. - } \\
\text { Mar. }\end{array}$ & $\begin{array}{l}93 \\
(62-147)\end{array}$ & 15 & $\begin{array}{l}\text { Apr.- } \\
\text { May }\end{array}$ & 62.50 \\
\hline $1995-96$ & 3 & $\begin{array}{l}4.6 \\
(4-5)\end{array}$ & 14 & $\begin{array}{l}\text { Oct. } \\
\text { Dec. }\end{array}$ & $\begin{array}{l}109 \\
(109)\end{array}$ & 3 & Apr. & 21.42 \\
\hline $1996-97$ & 6 & $\begin{array}{l}5.5 \\
(5-8)\end{array}$ & 33 & $\begin{array}{l}\text { Oct.- } \\
\text { Mar. }\end{array}$ & $\begin{array}{l}193 \\
(191-195)\end{array}$ & 2 & May & 6.06 \\
\hline $1997-98^{*}$ & - & - & - & - & - & - & - & - \\
\hline $1998-99$ & 5 & $\begin{array}{l}7.4 \\
(4-12)\end{array}$ & 37 & $\begin{array}{l}\text { Jan.- } \\
\text { Mar. }\end{array}$ & $\begin{array}{l}95 \\
(73-108)\end{array}$ & 27 & $\begin{array}{l}\text { Apr. } \\
\text { May }\end{array}$ & 72.97 \\
\hline Total & 34 & - & 200 & $\begin{array}{l}\text { Oct.- } \\
\text { Apr. }\end{array}$ & - & 100 & $\begin{array}{l}\text { Apr.- } \\
\text { June }\end{array}$ & 49.26 \\
\hline $\begin{array}{l}\text { Aver } \\
+\end{array}$ & 4.8 & 5.81 & 28.57 & $\begin{array}{l}\text { Oct.- } \\
\text { Mar. }\end{array}$ & 108.42 & 14.28 & $\begin{array}{l}\text { Apr.- } \\
\text { May }\end{array}$ & 46.81 \\
\hline
\end{tabular}

NC - Number of clutch; CS - Clutch size; NE - Number of eggs; IP - Incubation period; NS - Number of successes; HM - Hatching months; * Females did not lay eggs for reasons unknown; + Average calculated for a total of seven years.
Nest and nesting season: Nesting of the species was recorded during October to April with the peak between January and February (Figure 1). During the year 1997-1998, I had not recorded any nest or nesting activities in all the five females.

During the eight years of my study, 34 nests were prepared by the five females, at a rate of 0.97 nest/female per year, it means each female did not take part in breeding during a calendar year. Only four and three nests are recorded during the year of 19911992 and 1995-1996, respectively. Also, it was noted that in 1993-94 and 1996-97, six nests were recorded each year. This indicates that one female laid eggs twice in these years (Table 1).

Clutch and egg size: A total of 34 nests were observed during eight years of study which shows that an average of 4.85 nests/ year. Average clutch size was $5.81(n=34)$ which ranged from 312 eggs. An average of 159 eggs shows the following egg dimensions: 47.3 x $25.5 \mathrm{~mm}$ (LxW) and $17.89 \mathrm{~m}$ weight.

Incubation period and success: The incubation period recorded varied from 64 to 195 days with an average of 108.4 days. All eggs hatched simultaneously or within two days. However, during the year 1993 and 1996, with regard to nest no.11 and nest no.24 hatching was observed for five days.

During the study hatching success observed was an average of 48. 81 per cent per year, with the highest success of 78.78 per cent in 1993-94 and lowest success of 6.06 per cent observed in 1996-97.

Hatchling season, colour and size: The hatching season was recorded from April to June with peak period in during April (Figure 2). Newly hatched hatchlings are bright in colour. The measurements and weights of 62 hatchlings are given in Table 2.

All the hatchlings were very active, the carapace was brownish or olive green with red or orange stripe along the first three vertebrals, the marginals bordered with yellow. Plastron was orange with two to four faded black markings on each scutes.

Maturity: Each hatchling was kept in separate rearing pens, with marginal scutes clipped to identify year wise breeding stocks.

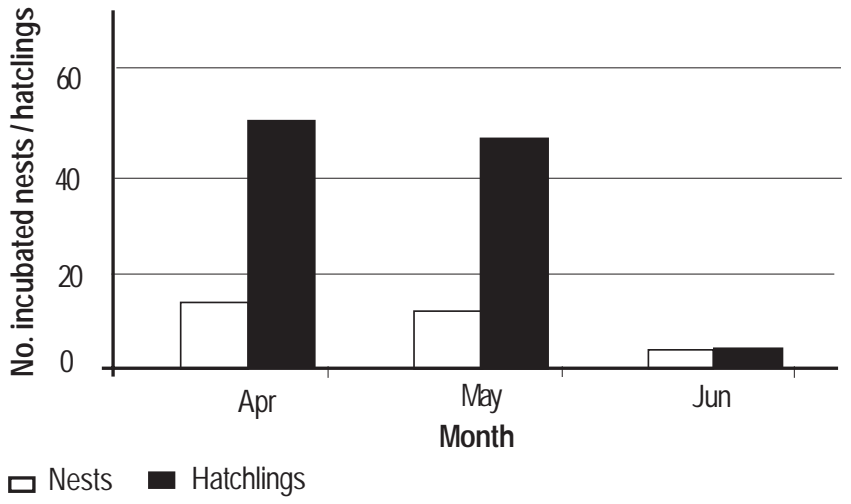

Figure 2. Month wise incubated eggs and hatchlings 
Table 1. Year-wise breeding data of Kachuga tecta from 1991 to 1999, clucth and date of laying, incubation date and period

\begin{tabular}{|c|c|c|c|c|c|c|c|c|c|}
\hline \multirow[t]{2}{*}{ Nest No. } & \multirow[t]{2}{*}{ Clutch } & \multicolumn{3}{|c|}{ Average Egg Size } & \multirow{2}{*}{$\begin{array}{l}\text { Date of } \\
\text { laying eggs }\end{array}$} & \multirow{2}{*}{$\begin{array}{l}\text { Date of } \\
\text { incubation }\end{array}$} & \multirow{2}{*}{$\begin{array}{l}\text { No. of } \\
\text { hatchlings }\end{array}$} & \multirow{2}{*}{$\begin{array}{l}\text { Incubation } \\
\text { period }\end{array}$} & \multirow{2}{*}{$\begin{array}{l}\% \\
\text { success }\end{array}$} \\
\hline & & Width & Weight & Length & & & & & \\
\hline $1(1991-92)$ & 5 & $4.40(4.35-4.45)$ & $2.52(2.50-2.60)$ & $17.4(15-19)$ & 04.11 .91 & - & - & - & - \\
\hline 2 & 6 & $4.12(4.05-4.26)$ & $2.41(2.40-2.46)$ & $17.6(15-20)$ & 24.02 .92 & 01.05.92 & 6 & 66 & 100 \\
\hline 3 & 5 & $4.18(4.00-4.46)$ & $2.38(2.40-2.56)$ & $17.4(12-23)$ & 26.02 .92 & - & - & - & - \\
\hline 4 & 7 & $4.39(4.35-4.46)$ & $2.49(2.40-2.56)$ & $17.7(15-20)$ & 03.04 .92 & 06.06 .92 & 1 & 64 & 14.2 \\
\hline $5(1992-93)$ & 7 & 4.20 & 2.35 & 18.0 & 25.01 .93 & 04.05 .93 & 7 & 98 & 100 \\
\hline 6 & 10 & 4.18 & 2.50 & 19.0 & 20.02 .93 & 09.05 .93 & 4 & 78 & 40 \\
\hline 7 & 6 & 4.30 & 2.44 & 18.2 & 20.02 .93 & 09.05 .93 & 5 & 78 & 83.3 \\
\hline 8 & 8 & $4.34(4.28-4.43)$ & $2.50(2.30-2.62)$ & $18.5(17-20)$ & 24.02 .93 & 06.05 .93 & 4 & 71 & 50 \\
\hline 9 & 5 & $4.38(4.15-4.50)$ & $2.43(2.37-.2 .50)$ & $18.6(17-20)$ & 20.03 .93 & - & - & - & - \\
\hline 10(1993-94) & 4 & $4.26(4.20-4.35)$ & $2.53(2.48-2.60)$ & $20.2(20-21)$ & 31.10 .93 & 17.04 .93 & 2 & 168 & 50 \\
\hline \multirow[t]{2}{*}{11} & 6 & $4.27(4.08-4.50)$ & $2.60(2.55-2.66)$ & $18.8(16-21)$ & 13.11 .93 & 17.04 .93 & 2 & 155 & 83.3 \\
\hline & & & & & & 20.04 .93 & 3 & 160 & \\
\hline 12 & 6 & $4.33(4.00-4.50)$ & $2.46(2.43-.2 .55)$ & $11.8(19-21)$ & 31.12 .93 & 21.04 .93 & 5 & 112 & 83 \\
\hline 13 & 5 & $4.38(4.15-4.50)$ & $2.43(2.37-2.50)$ & $18.6(17-20)$ & 07.01 .94 & 21.04 .94 & 2 & 108 & 40 \\
\hline 14 & 6 & $4.57(4.43-4.72)$ & $2.50(2.45-2.55)$ & $17.3(15-18)$ & 10.01 .94 & 24.04 .94 & 6 & 108 & 100 \\
\hline \multirow[t]{2}{*}{15} & 6 & $4.43(4.10-4.55)$ & $2.48(2.45-2.52)$ & $16.6(15-18)$ & 21.01 .94 & 21.04 .94 & 5 & 90 & 100 \\
\hline & & & & & 22.04 .94 & & 1 & 91 & \\
\hline 16(1994-95) & 5 & $4.41(4.25-4.57)$ & $2.51(2.45-2.56)$ & $16.4(15-18)$ & 22.11.94 & 18.04 .95 & 2 & 147 & 40 \\
\hline 17 & 5 & 4.67 & 2.55 & 13.5 & 20.02 .95 & 19.05 .95 & 3 & 88 & 60 \\
\hline 18 & 5 & $4.38(4.05-4.65)$ & $2.70(2.60-2.78)$ & $17.7(15.5-19)$ & 01.03 .95 & 02.05 .95 & 2 & 62 & 40 \\
\hline 19 & 9 & $4.16(4.05-4.22)$ & $2.53(2.42-2.63)$ & $16.1(15.5-17)$ & 01.03 .95 & 14.05 .95 & 8 & 75 & 88.8 \\
\hline 20 & $3^{*}$ & $4.36(4.35-4.37)$ & $2.58(2.55-2.62)$ & $16.5(16.5)$ & 19.05 .95 & - & - & - & - \\
\hline $21(1995-96)$ & $4+$ & $4.48(4.45-4.55)$ & $2.60(2.60-2.65)$ & 17.8(17.8-18) & 22.10 .95 & - & - & - & - \\
\hline 22 & 5 & $4.40(4.30-4.55)$ & $2.57(2.55-2.60)$ & $17.1(16.5-18)$ & 25.10 .95 & - & - & - & - \\
\hline 23 & 5 & $4.40(4.20-4.58)$ & $2.54(2.51-2.60)$ & $17(16-17.5)$ & 18.12 .95 & 07.04 .96 & 3 & 109 & 60 \\
\hline \multirow[t]{2}{*}{$24(1996-97)$} & 5 & $4.59(4.50-4.66)$ & $2.67(2.60-2.70)$ & $19(18-20)$ & 30.10 .96 & 10.05 .97 & 1 & 191 & 40 \\
\hline & & & & & & 14.05 .97 & 1 & 195 & \\
\hline 25 & 5 & $4.67(4.40-4.85)$ & $2.68(2.65-2.70)$ & $19.8(19-21)$ & 30.10 .96 & - & - & - & - \\
\hline 26 & 5 & $4.62(4.48-4.80)$ & $2.67(2.65-2.70)$ & $19.1(18-20)$ & 04.11 .96 & - & - & - & - \\
\hline 27 & 8 & $4.29(4.20-4.40)$ & $2.58(2.40-2.68)$ & $17.315 .5-18.5$ & 08.12 .96 & - & - & - & - \\
\hline 28 & $5+$ & $4.50(4.35-4.60)$ & $2.61(2.55-2.62)$ & $18.2(17.5-19)$ & 11.01 .97 & - & - & - & - \\
\hline 29 & 5 & $4.35(4.30-4.42)$ & $2.66(2.60-2.70)$ & $18.2(17-18.5)$ & 29.03 .97 & - & - & - & - \\
\hline $30(1998-99)$ & 8 & $4.33(4.15-4.55)$ & $2.63(2.53 .2 .65)$ & $17.4(16-18.5)$ & 10.01 .99 & 23.04 .99 & 7 & 103 & - \\
\hline 31 & 12 & $4.51(4.36-4.70)$ & $2.63(2.53 .2 .68)$ & $18.5(17.5-19.5)$ & 10.01 .99 & 28.04 .99 & 8 & 108 & - \\
\hline 32 & 7 & $4.15(4.00-4.40)$ & $2.50(2.15-2.75)$ & $15.2(12-18.5)$ & 18.01 .99 & 24.04 .99 & 6 & 96 & - \\
\hline 33 & 4 & - & - & - & 07.02 .99 & - & - & - & - \\
\hline 34 & 6 & - & - & - & 01.03 .99 & 12.05 .99 & 6 & 73 & - \\
\hline
\end{tabular}

* Eggs found from water; + Hatchlings that did not come out of the nest

Table 2. Measurements of hatchlings $(n=61)$

\begin{tabular}{lllllllll}
\hline Size & SCL & CCL & SCW & CCW & PL & PW & H & W \\
\hline Big & 364 & 405 & 315 & 420 & 325 & 273 & 287 & 11.0 \\
Small & 300 & 350 & 240 & 360 & 275 & 205 & 170 & 08.5 \\
Av(SD) & 337.5 & 378.9 & 290.0 & - & 300.7 & - & 199.4 & 09.0 \\
& $(+/-13.81)$ & $(+-13.02)$ & & & $(+-10.62)$ & & $(+/-18.87)$ & $(+/-0.63)$ \\
\hline
\end{tabular}

SCL - Straight carapace length; CCL - Curved carapace length; SCW - Straight carapace width; CCW - Curved carapace width; PL - Plastron length ; PW - Plastron width; $\mathrm{H}$ - Height; W -Weight 


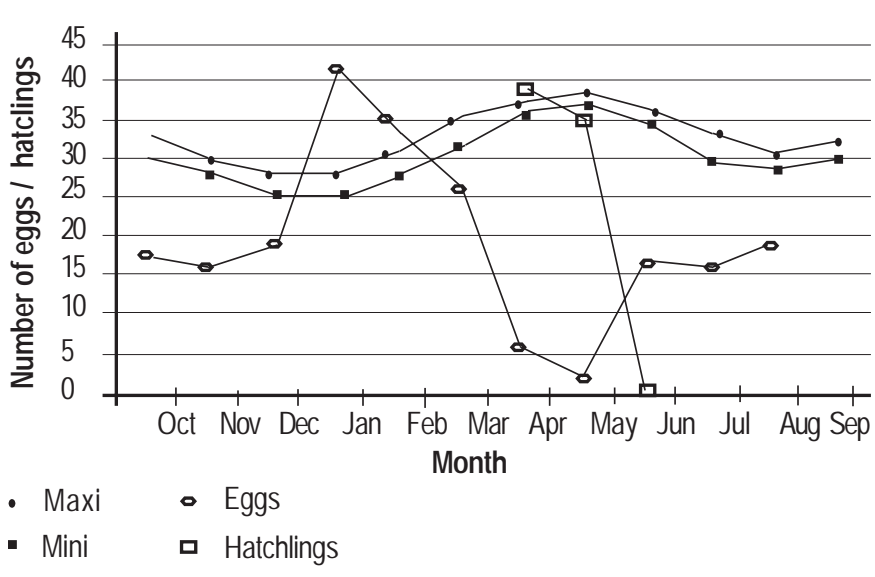

Figure 3. Relationship of egg production / hatchlings with temperature

Maturity was recorded at the age of three years in breeding stock of year 1991-92 and 1993-94, after the 1995-96 and 1979-98, respectively.

Five females laid totally 200 eggs, of which 100 hatchlings were achieved and only 40 reached maturity at the age of three years. Remaining hatchlings were lost due to endoparasitic infection, fungus and unknown reasons, during the study period.

Temperature and breeding season: Egg production and average temperature (minimum and maximum) showed a strong negative correlation. The temperature increased gradually from October to December and it decreased to $27.13^{\circ} \mathrm{C}$ (max.) in January. The temperature again gradually increased up to $38.56^{\circ} \mathrm{C}$ (max.) in May and decreased. The egg laying activity in females followed the same trend. Five nests with 23 eggs were laid in October and further it decreased to three nests and 19 eggs in December. Again nesting activity was high with eight nests and 56 total egg production in January and decreased (Figure 3). High numbers of hatchlings emerged when the temperatures was highest in April and May.

\section{Discussion}

The breeding season of Kachuga tecta was observed for almost eight months, with courtship in September to the emergence of the hatchlings in June. Nesting period was observed for eight months from October to May, which is similar to the earlier studies (Vijaya, 1982; Duda \& Gupta, 1982; Moll, 1987).

Present clutch size is an average of 4.85 per month with the range of 3 to 12 eggs, which quite noticeably differs from the earlier record of 4 to 10 eggs in Jammu area of northern India (Duda \& Gupta, 1982). The largest clutch size of 12 eggs was due to larger female (curved carapace length $23 \mathrm{~cm}$ ) in the study.

The mean dimension ( $47.3 \times 25.3 \mathrm{~mm}, 17.8 \mathrm{~g}$ weight $)$ is larger than that recorded in northern population of the species (Moll, 1987).

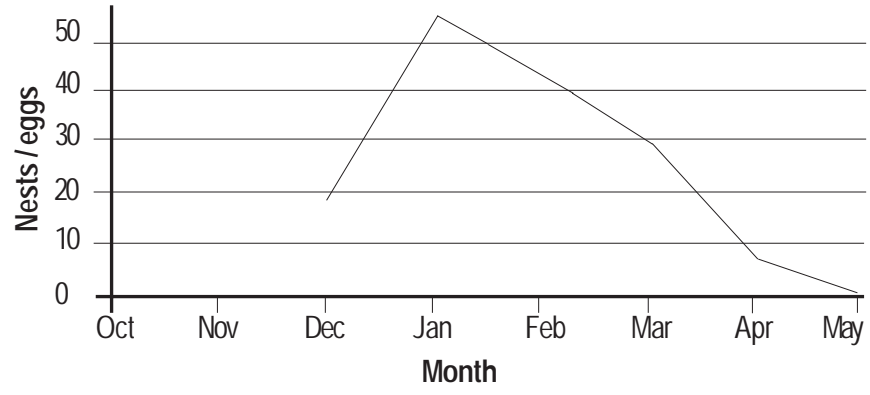

Figure 4. Nesting period and egg production nests / eggs

The incubation period varied from 64 to 195 days in the present study, which may be due to micro-climatic condition and habitat structure.

All the five females did not breed for two years (1992-1993 and 1995-1996) and in another two years (1993-1994 and 1996-1997) a female laid eggs twice in the season. In addition, in 1997-1998 none of the females laid eggs. This type of breeding performance indicates following possibilities - there may not be similar trends in the breeding of this species; some climatic factors such as temperature strongly influence the breeding activities; different age group of the females in the study.

During 1996-1997, breeding success of very low 6.06 per cent was observed due to rains, which occurred in January 1997. This rain has not only affected the nests but also it might have affected preceeding breeding season 1997-1998 (none of the females laid eggs). These observations also support the role of rains in the breeding performance of Kachuga tecta.

\section{References}

Das, I. (1995). Indian Turtles a Field Guide. WWW - India (Eastern region), Calcutta, 119pp.

Duda and Gupta (1982). Trans abdominal migration of ova in some freshwater turtles. Proceedings of Indian Academy of Science (Animal Science) 91: 189-197.

Mishra, S.B. (1984). Mishra writes from the Chambal Sanctuary. Hamadryad 10(3): 18.

Moll, E.O. (1987). Survey of the freshwater turtles of India, the genus Kachuga part II. Journal of the Bombay Natural History Society 84(1): $7-25$.

Vijaya, J. (1982). Kachuga tecta hatching at the Snake Park. Hamadryad 7(3): 14-15.

Vyas, R. and B.H. Patel. (1993). Captive breeding of the Indian Roofed Terrapin Kachuga tecta (Gray). Journal of the Bombay Natural History Society 90(1): 109-112. 